\title{
26. ORGANIC GEOCHEMISTRY OF SOME LOWER CRETACEOUS SHALES FROM DEEP SEA DRILLING PROJECT SITE 416, EASTERN NORTH ATLANTIC
}

\author{
G. Deroo, J. P. Herbin, J. Roucaché, and B. Tissot, Institut Français du Pétrole, Division Géologie, \\ Rueil-Malmaison, France
}

\begin{abstract}
Siltstone and mudstone sampled from Valanginian to Hauterivian turbidite sequences at DSDP Site $416,(2 \mathrm{~km}$ from Site 370 ) contain relatively low organic-carbon contents. The organic material is predominantly of continental origin and in an immature stage of evolution.
\end{abstract}

\section{INTRODUCTION}

The study was made to characterize the geochemistry of the organic matter of some samples from the Valanginian to Hauterivian drilled at Site 416 (Figure 1). The pyrolysis assay of raw samples was followed by a chloroform extraction. Elemental analysis of kerogen and determination of the humic fraction then were conducted to complete the geochemical characterization.

We examined six samples from graded turbidite sequences (i.e., coarse-grained at base and graded upward) through terrigenous and carbonate zones.

The terrigenous components dominate and are composed mainly of fine sandstone, siltstone, and mudstone. The samples are Hauterivian to Valanginian (Figure 2).

The analytical procedures are outlined in Figure 3 and were described previously in our Legs 47A and 47B reports (Deroo et al., 1978a, 1978b).

\section{DETAILED RESULTS}

\section{Carbon}

All the samples have a low content of mineral carbon (Table 1), including the sample from Section 416A-48-2, which contains carbonate cycles (Site 416 report, this volume). Organic-carbon content is low and decreases downward (Table 1).

\section{Pyrolysis Assay and Organic Matter Characterization}

Pyrolysis was performed for the second time aboard the Glomar Challenger during Leg 50; results are given in Table 1 and Figure 4.

The method (Espitalié et al., 1977) allows a characterization of the type and maturation of the sedimentary organic material. Pyrolysis was applied in the same manner for our shore-based studies. Figure 4 shows a plot of the values of hydrogen and oxygen indexes related to the weight of organic carbon (see also Table 1). These indexes allow a characterization of the organic matter in the untreated rock (Espitalié et al., 1977) in the same way that the Van Krevelen diagram (H/C ver- sus $\mathrm{O} / \mathrm{C}$ ) can be used for the isolated kerogen fraction (Tissot et al., 1974).

All the studied samples are located on the evolution path of kerogen type III or below, indicating that they contain more-or-less altered organic material of continental origin.

The range of hydrogen indexes from shore-based analysis (60 to 80 ) is comparable with shipboard data ( 30 to 80 ), when material from Cores $416 \mathrm{~A}-9$ through 416 A-28 considered.

The temperatures of the pyrolysis-maximum peak (Table 1) correspond to an immature stage (indicated by peak generation in the 400 to $440^{\circ} \mathrm{C}$ range), before the principal zone of oil formation. This has been found also for Cretaceous sediments at other DSDP sites in the Atlantic Ocean.

\section{Humic Compounds}

Humic compounds were isolated from the kerogen fractions of the six samples. The content of humic compounds (humic + fulvic acids) is expressed as a percentage of the total organic carbon (Table 2). The humic fraction for an immature material of type III is up to 15 per cent or more of total organic carbon (Huc et al., 1977).

For the studied samples, the range was 14 to 17 per cent. Such a range definitely indicates immature samples; however, it does not allow specification of type II or type III material. A mixture of types II and III more probably can be invoked to account for the data. Comparable data were obtained for a type III material of Aptian age at Site 398 (Vigo area) at 1600 meters subbottom depth (Deroo et al., 1978b).

\section{Kerogen Fraction}

Kerogen elemental analysis was conducted on the same six samples (Table 3; Figure 5). The preparation consisted of $\mathrm{HCl}$ and $\mathrm{HF}$ treatment under nitrogen atmosphere. The data are plotted on a Van Krevelen diagram and compared to the three reference evolution paths of kerogen types I, II, and III (Tissot et al., 1974). The six kerogen values are located above the hydrogen- 


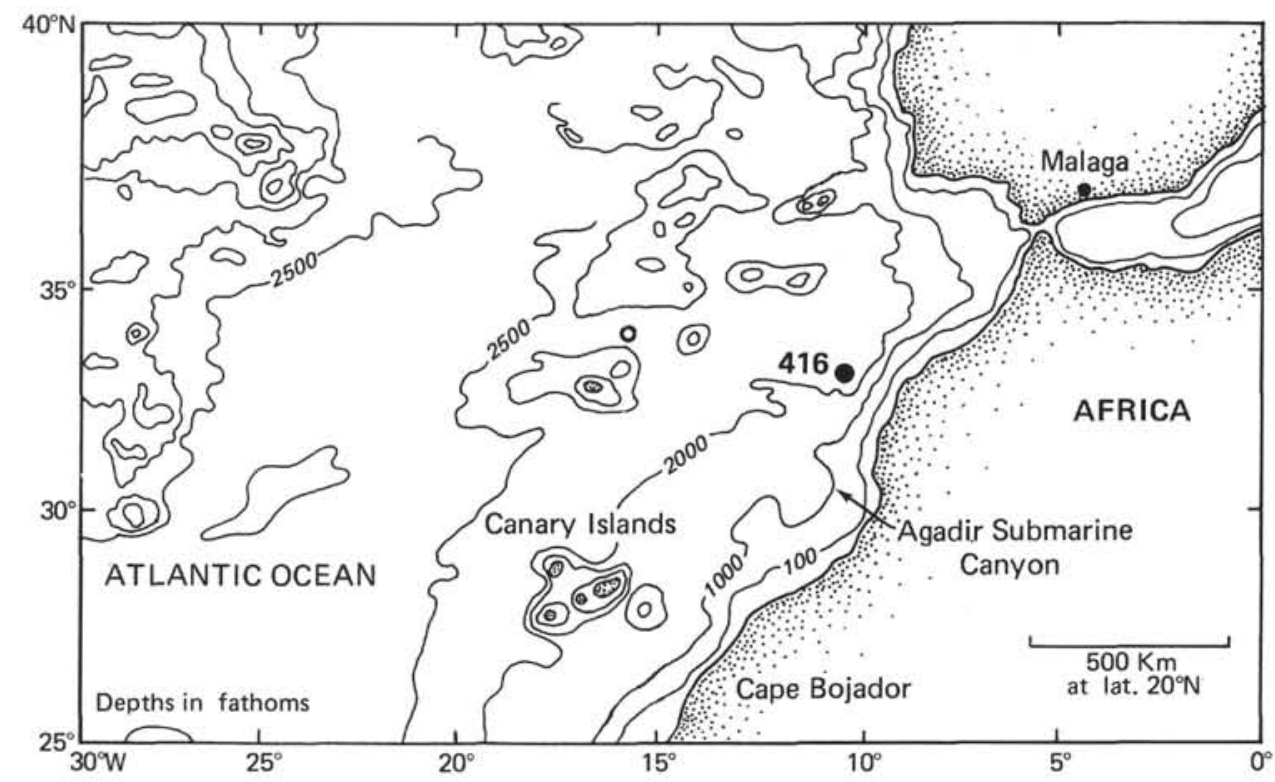

Figure 1. Location of DSDP Site 416.

poor type-III trend for most of the samples. This suggests some contribution of marine type II in addition to the main type III of continental origin. The sample from Section 416A-48-2 revealed an abnormally high $\mathrm{O} / \mathrm{C}$ atomic ratio that can be related to a low organic content $(0.29 \%)$.

\section{Chloroform Extracts}

The samples provided a low chloroform extract, and the ratio of extract to organic carbon was also low (Table 4; Figure 6). When fractionated by the thin-layer chromatography method (Huc et al., 1976), the extracts yield a large NSO content of some 72 to 89 per cent and a saturated-plus-unsaturated hydrocarbon fraction ranging from 6 to 19 per cent.

For all the samples, gas chromatography of the $\mathrm{C}_{15}$ to $\mathrm{C}_{35}$ saturated plus unsaturated hydrocarbons shows a predominance of odd- over even-number normal alkanes from $\mathrm{C}_{21}$ to $\mathrm{C}_{35}$ and a maximum at the $\mathrm{C}_{27}$ $n$-alkane. A continental contribution from higher plants can account for this distribution. In addition, a marine planktonic contribution is indicated by a second maximum at $n-\mathrm{C}_{16}$ and $\mathrm{C}_{17}$ in samples from Sections 416A-14-4, 18-3, 28-4, and 48-2.

Fractionation of saturated and unsaturated hydrocarbons was not performed because of the low total hydrocarbon yield.

\section{CONCLUSIONS}

The mudstones and siltstones distributed in turbidites in the Valanginian to Hauterivian cores at Site 416 are characterized by organic matter of predominantly continental origin, but contain some subordinate marine material. As for other Atlantic Cretaceous material, an immature stage of evolution can be assigned to th studied samples.

\section{ACKNOWLEDGMENT}

The authors are indebted to Dr. C. Cornford, KFA, Jülich, for his comments and review of the paper.

\section{REFERENCES}

Deroo, G., Herbin, J. P., Roucaché, J., and Tissot, B., 1978a. Organic geochemistry of some organic-rich shales from DSDP Site 397, Leg 47A, eastern North Atlantic. In Ryan, W. B. F., Sibuet, J.-C. Initial Reports of the Deep Sea Drilling Project, v. 47, Pt. 1: Washington (U. S. Government Printing Office), p. 523-530.

1978b. Organic geochemistry of Cretaceous shales from DSDP Site 398, Leg 47B, eastern North Atlantic. In Ryan, W. B. F., Sibuet, J.-C. Initial Reports of the Deep Sea Drilling Project, v. 47, Pt. 2: Washington (U. S. Government Printing Office), p. 513-522.

Espitalié, J., Laporte, J. L., Madec, M., Marquis, F., Leplat, P., Paulet, J., Boutefeu, A., 1977. Méthode rapide de caractérisation des roches mr̀es, de leur potentiel pétrolier et de leur degré d'évolution, Rev. Inst. Franç. Pétrole, v. 32 , p. 23-42.

Huc, A. Y., Durand, B., 1977. Occurrence and significance of humic acids in ancient sediments, Fuel, v. 56, p. 73-80.

Huc, A. Y., Roucaché, J., Bernon, M., Caillet, G., and Da Silva, M., 1976. Application de la chromatographie sur couche mince à l'étude quantitative et qualitative des extraits de roche et des huiles, Rev. Inst. Franç. Pétrole, v. 31 , p. 67-98.

Tissot, B., Durand, B., Espitalié, J., Combaz, A., 1974. Influence of the nature and diagenesis of organic matter in the formation of petroleum, Am. Assoc. Petrol. Geol. Bull., v. 58, p. 499-506. 


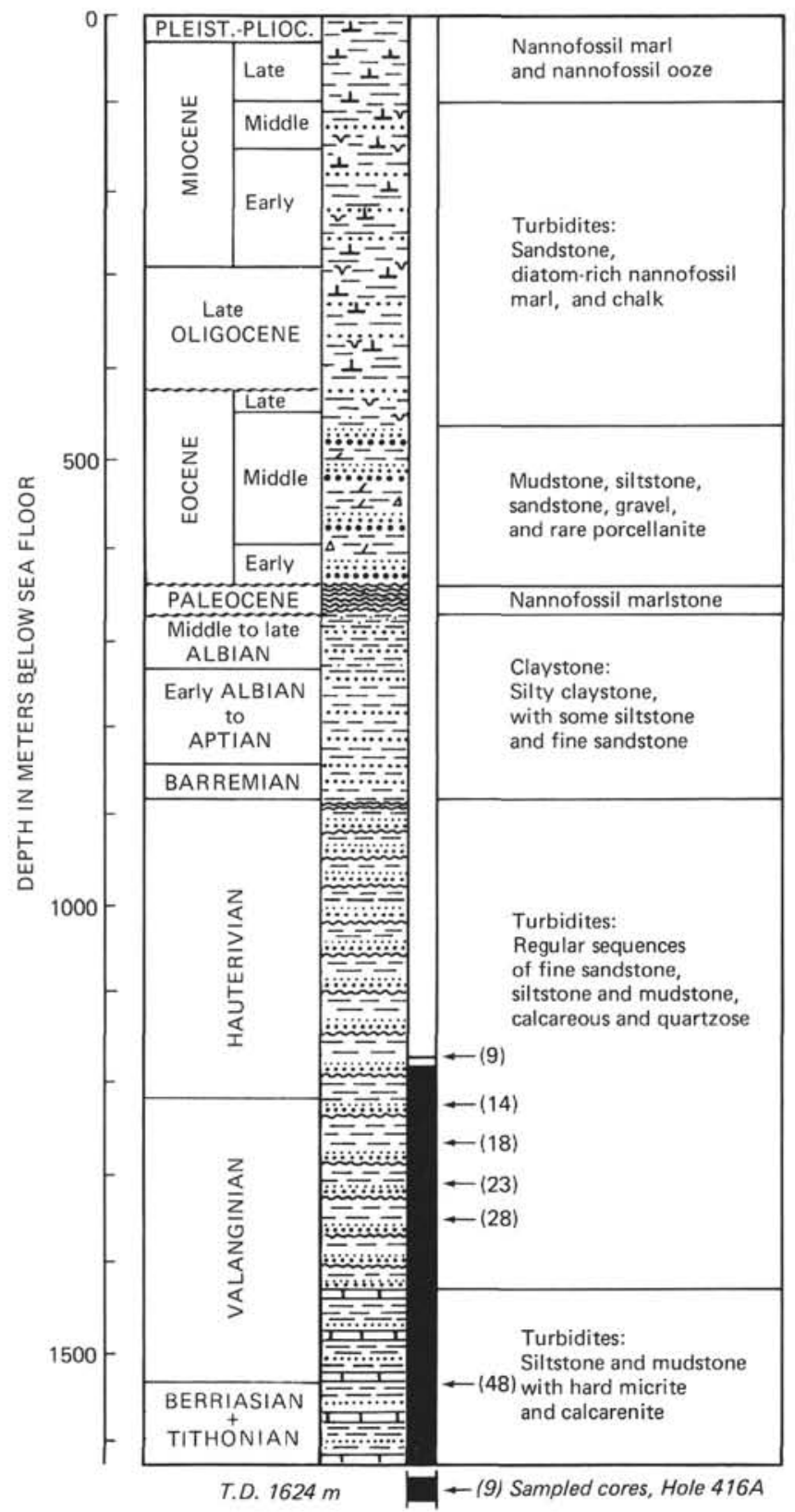

Figure 2. Stratigraphic location of sampled cores from Hole 416. 


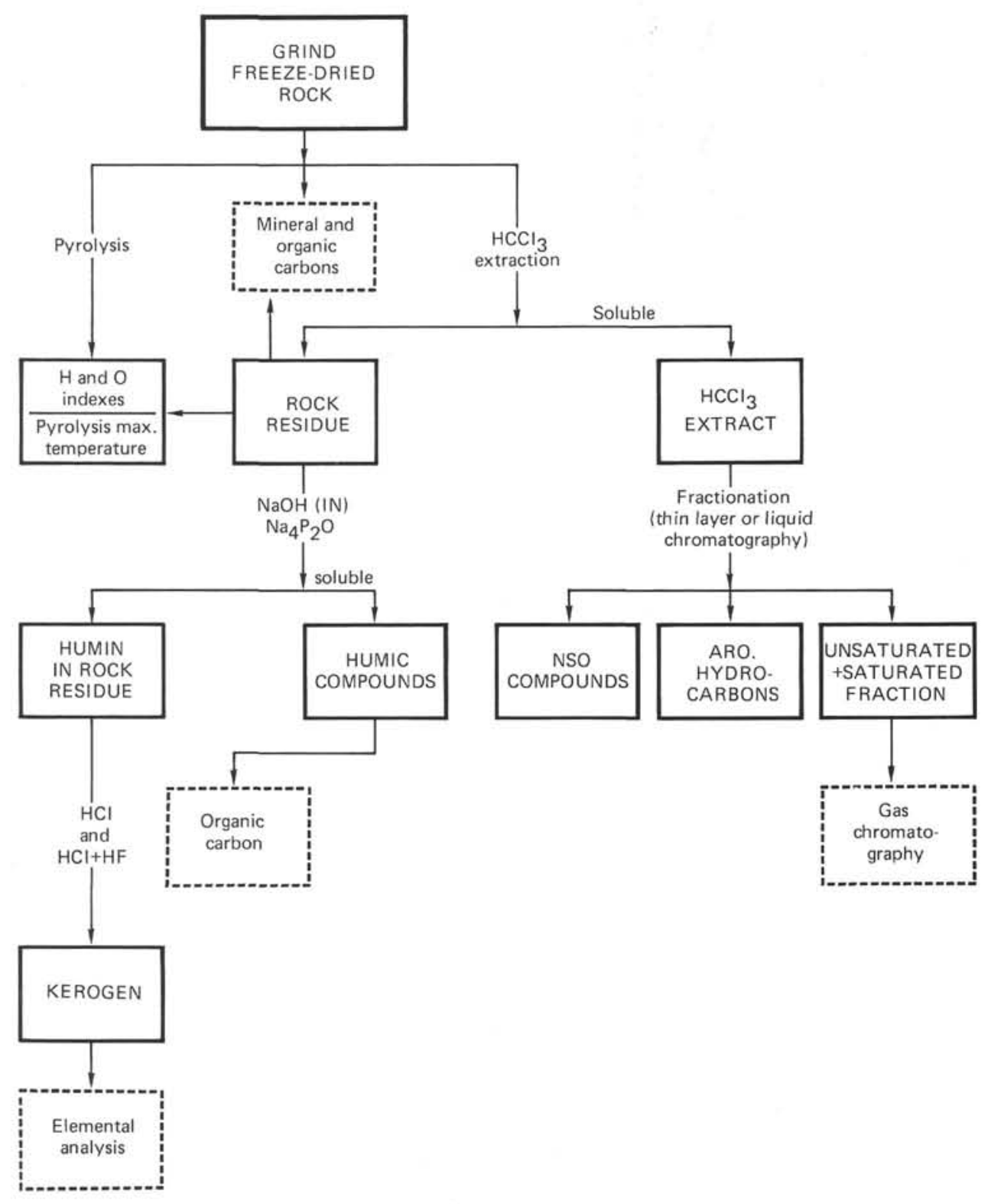

Figure 3. Schematic analytical procedures. 
TABLE 1

Carbon and Pyrolysis Assay Data, Site 416

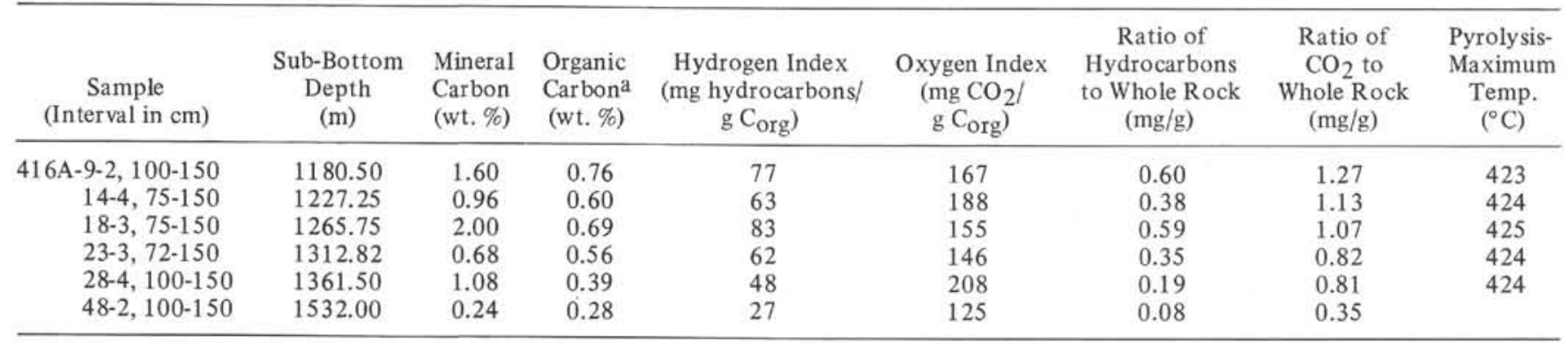

${ }^{\mathrm{a}}$ Raw samples.

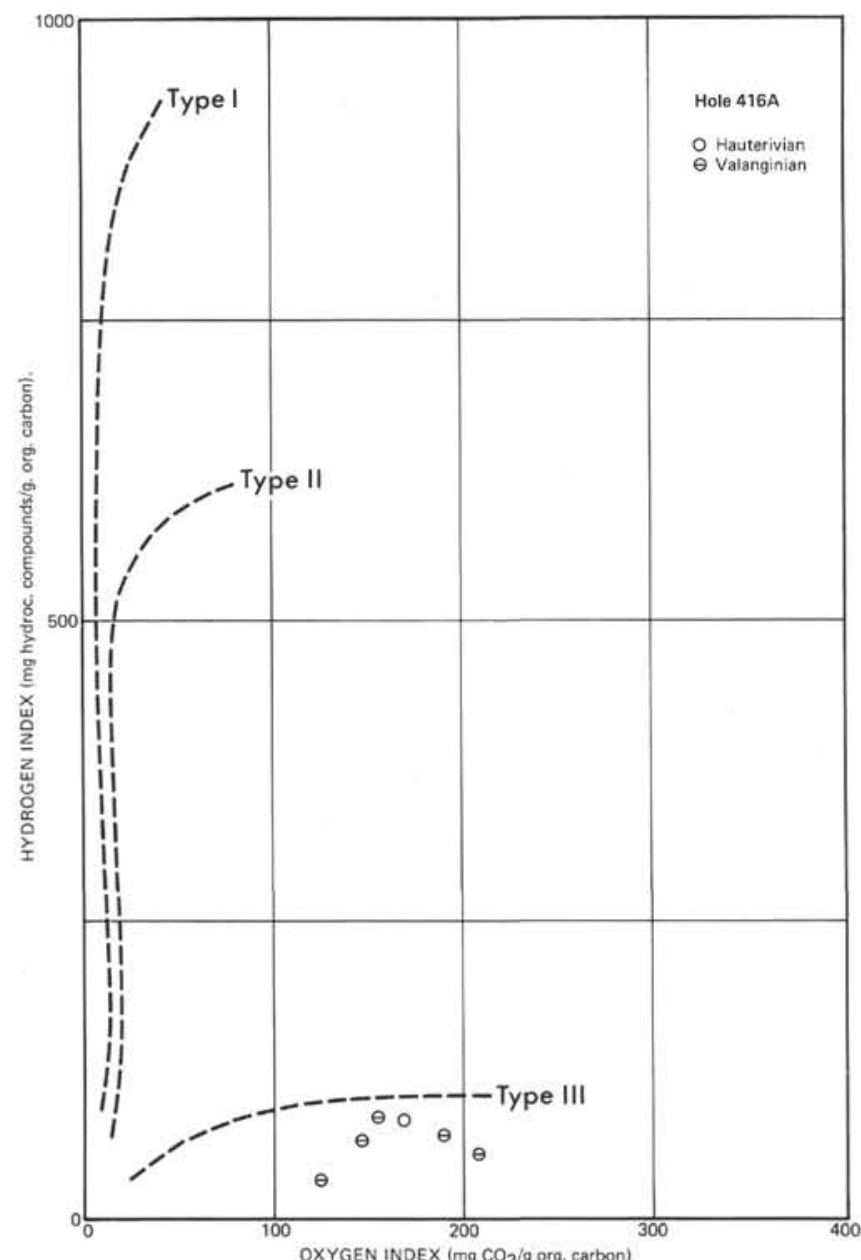

TABLE 2

Humic Compounds, Site 416

\begin{tabular}{ccc|cc}
\hline $\begin{array}{c}\text { Sample } \\
\text { (Interval in cm) }\end{array}$ & $\begin{array}{c}\text { Total } \\
\text { Subth } \\
\text { Bottom }\end{array}$ & $\begin{array}{c}\text { Organic } \\
\text { Carbon } \\
\text { (wt. \% } \\
\text { of rock) }\end{array}$ & $\begin{array}{c}\text { Humic } \\
\text { Carbon } \\
\text { (wt. \% } \\
\text { of rock) }\end{array}$ & $\begin{array}{c}\text { Humic } \\
\text { Carbon } \\
\text { (wt. \% } \\
\text { of total } \\
\text { C }_{\text {org) }}\end{array}$ \\
\hline 416A-9-2, 100-150 & 1180.50 & 0.63 & 0.09 & 14 \\
$14-4,75-150$ & 1227.25 & 0.48 & 0.08 & 16 \\
$18-3,75-150$ & 1265.75 & 0.67 & 0.11 & 16 \\
$23-3,75-150$ & 1312.82 & 0.52 & 0.07 & 13 \\
$28-4,100-150$ & 1361.50 & 0.35 & 0.06 & 17 \\
$48-2,100-150$ & 1532.00 & 0.29 & 0.04 & 14 \\
\hline
\end{tabular}

${ }^{\mathrm{a}}$ After $\mathrm{CHCl}_{3}$ extraction.

TABLE 3

Elemental Composition and Ash Content of Kerogens, Site 416

\begin{tabular}{|c|c|c|c|c|c|c|c|c|c|c|}
\hline \multirow{3}{*}{$\begin{array}{c}\text { Sample } \\
\text { (Interva! in } \mathrm{cm} \text { ) }\end{array}$} & \multirow{3}{*}{$\begin{array}{c}\text { Sub- } \\
\text { Bottom } \\
\text { Depth } \\
\text { (m) }\end{array}$} & \multicolumn{6}{|c|}{ Elemental Composition } & \multirow{3}{*}{$\begin{array}{l}\text { Ash } \\
\text { (wt. } \\
\text { \%) }\end{array}$} & \multirow{2}{*}{\multicolumn{2}{|c|}{$\begin{array}{l}\text { Atomic } \\
\text { Ratios }\end{array}$}} \\
\hline & & c & H & $\mathrm{N}$ & 0 & $\mathbf{s}$ & $\mathrm{Fe}$ & & & \\
\hline & & \multicolumn{6}{|c|}{ (wt. \%, ash-free) } & & $\mathrm{H} / \mathrm{C}$ & $\mathrm{O} / \mathrm{C}$ \\
\hline $416 \mathrm{~A}-9-2,100-150$ & 1180.50 & 36.4 & 3.3 & 1.6 & 9.2 & 20.7 & 17.5 & 33.6 & 1.09 & 0.19 \\
\hline $14-4,75 \cdot 150$ & 1227.2 & 34.0 & & & & & 19 & 36.1 & 1.06 & 0.22 \\
\hline $18-3,75 \cdot 150$ & 1265.75 & 45.4 & 4.0 & 1.4 & 12.7 & 17.6 & 15 & 23.0 & 1.05 & 0.21 \\
\hline & 1312. & 39.0 & 3.3 & 1.3 & 11.3 & 21.8 & 18.2 & 27.3 & 1.01 & 0.21 \\
\hline $28-4,100-150$ & 1361.50 & 47.6 & 4.0 & 1.3 & 19.2 & 10.6 & 7. & 17.3 & 1.01 & 0.30 \\
\hline $48-2,100-150$ & 1532.00 & 39.4 & 3.5 & 0.9 & 20.9 & 12.6 & 10.3 & 25.0 & 1.07 & 0.40 \\
\hline
\end{tabular}

Figure 4. Pyrolysis assays, hydrogen and oxygen indexes. 


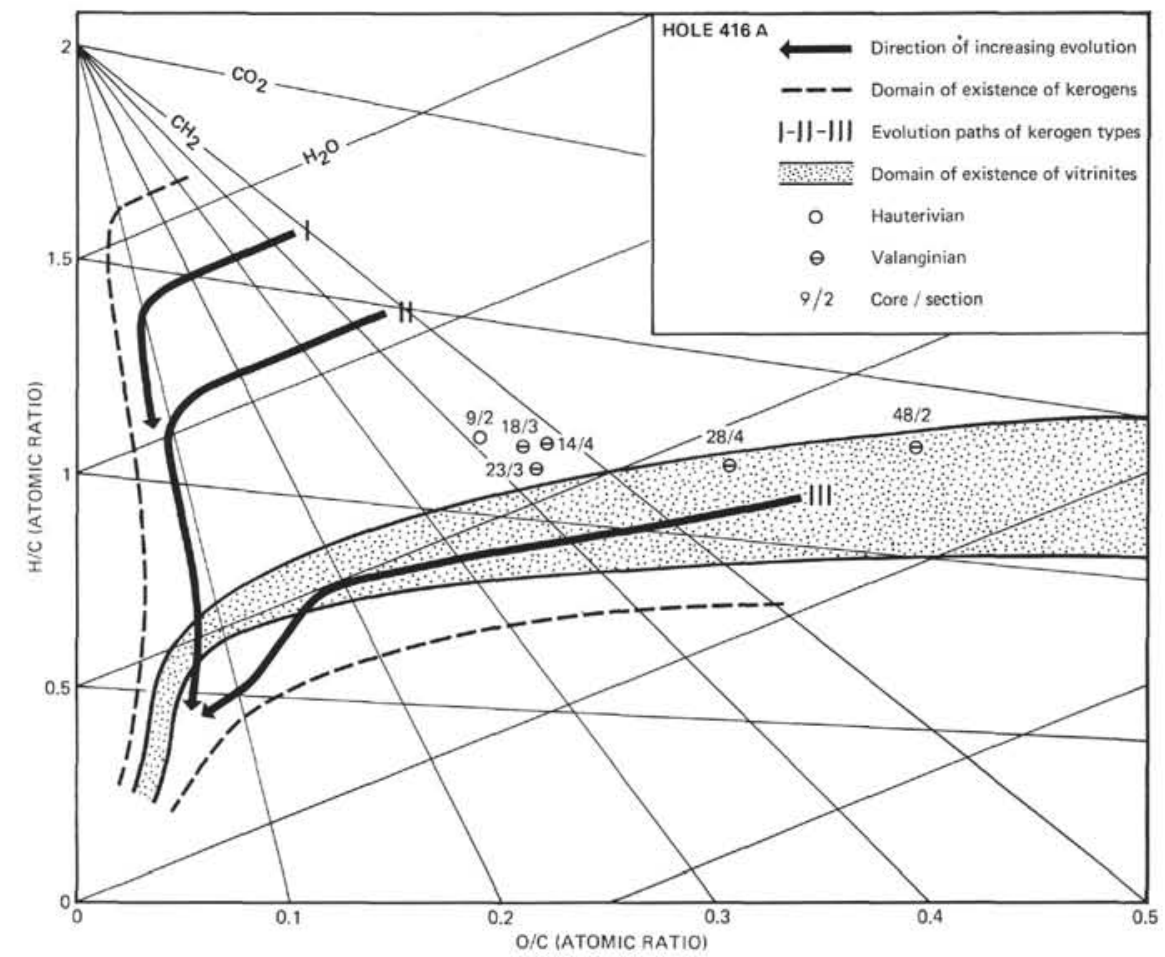

Figure 5. Kerogens: $\mathrm{H} / \mathrm{C}$ and $\mathrm{O} / \mathrm{C}$ diagram.

TABLE 4

Composition of Chloroform Extracts, Site 416

\begin{tabular}{|c|c|c|c|c|c|c|c|}
\hline \multirow[b]{2}{*}{$\begin{array}{c}\text { Sample } \\
\text { (Interval in } \mathrm{cm} \text { ) }\end{array}$} & \multirow{2}{*}{$\begin{array}{l}\text { Sub-Bottom } \\
\text { Depth } \\
\text { (m) }\end{array}$} & \multirow{2}{*}{$\begin{array}{l}\mathrm{CHCl}_{3} \\
\text { Extract } \\
\text { (mg) }\end{array}$} & \multicolumn{2}{|c|}{ Quantity of Extract } & \multicolumn{3}{|c|}{$\begin{array}{r}\text { Thin-Layer Chromatography Fractionation } \\
\text { Hydrocarbon Fractions }\end{array}$} \\
\hline & & & $\begin{array}{l}\text { (wt. \% } \\
\text { of rock) }\end{array}$ & $\begin{array}{l}\text { of total } \\
\left.\mathrm{C}_{\text {org }}\right)\end{array}$ & $\begin{array}{l}\text { NSO Compounds } \\
(\%)\end{array}$ & $\begin{array}{l}\text { Aromatics } \\
(\%)\end{array}$ & $\begin{array}{l}\text { Sat.+ Unsat. } \\
(\%)\end{array}$ \\
\hline $416 \mathrm{~A}-9-2,100-150$ & 1180.50 & 29.7 & 0.026 & 0.0394 & 84 & 7 & 9 \\
\hline $14-4,75-150$ & 1227.25 & 35.2 & 0.021 & 0.0406 & 79 & 9 & 12 \\
\hline $18-3,75-150$ & 1265.75 & 36.8 & 0.029 & 0.0412 & 77 & 10 & 13 \\
\hline $23-3,72-150$ & 1312.82 & 37.3 & 0.025 & 0.0458 & 81 & 6 & 13 \\
\hline $28-4,100-150$ & 1361.50 & 30.4 & 0.014 & 0.0397 & 89 & 5 & 6 \\
\hline $48-2,100-150$ & 1532.00 & 12.6 & 0.009 & 0.0314 & 72 & 9 & 19 \\
\hline
\end{tabular}



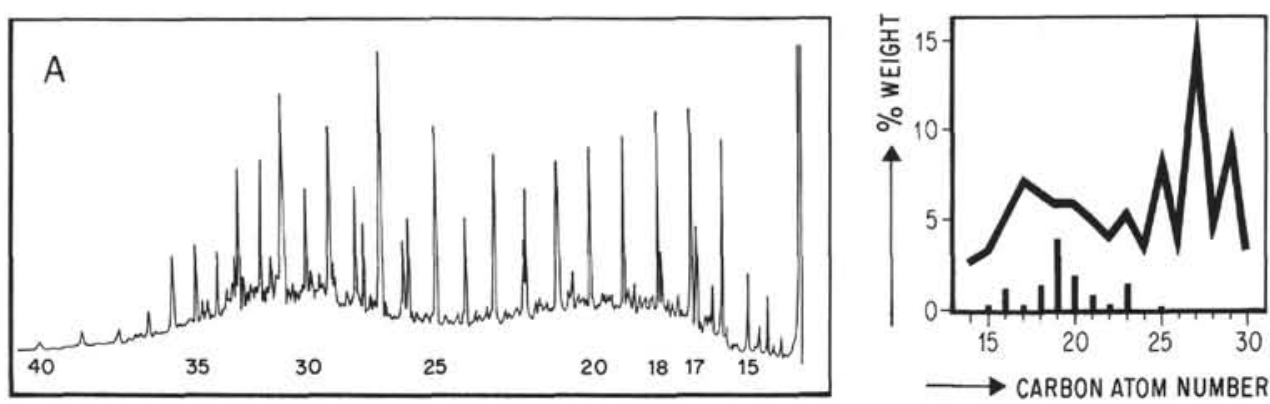

CARBON ATOM NUMBER
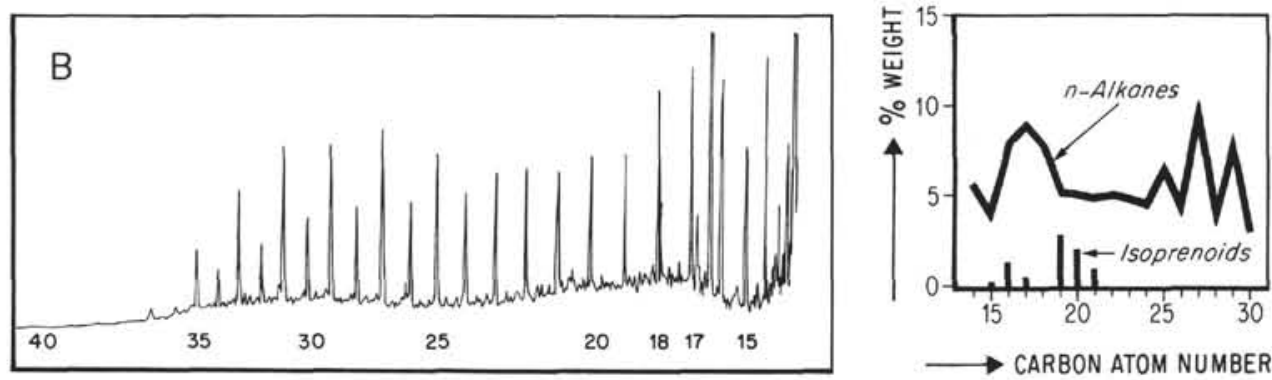

Figure 6. Extracts: Gas chromatography (A) Section 416A-14-4 saturated plus unsaturated hydrocarbons. (B) Section 416-48-2 saturated plus unsaturated hydrocarbons. 